\title{
A cognitive-pragmatic view of the French epistemic future
}

\section{LOUIS DE SAUSSURE and PATRICK MORENCY}

Université de Neuchâtel (Institut des Sciences du Langage et de la Communication)

(Received August 2009; revised June 20 I ; first published online I I August 20 I I)

\section{A B S T RAC T}

In this paper, we review the various types of epistemic usages of the (simple and anterior) future tenses in French with the assumption that what actually licenses their occurrence is not a semantic feature such as aspect but pragmatic effects that give relevance to the utterance at the moment of speech. We review the main hypotheses proposed in the relevant literature and conclude that epistemic futures seem to fulfill the function of communicating - through a metarepresentation of a future verification - not only epistemic modality and evidentiality, but also, and perhaps especially, the inference that a particular course of action has to be undertaken from the perspective of a state of affairs that is true in the present.

\section{INTRODUCTION ${ }^{1}$}

The aim of this paper is to investigate the manifestation of a (subjective) epistemic ${ }^{2}$ attitude by means of morphemes that denote a future temporal quantification of the eventuality in French, as in Ce sera le facteur uttered just after the bell has rung. French scholars also refer to this usage of the future tense as the 'putative future' (futur putatif, Damourette et Pichon, I9I I-I936) or the 'conjectural future' (future conjectural, Wilmet, I976), and usually distinguish it from other types of epistemic utterances with the future tense because of its particular flavour of probability. In English, similar cases are documented with will, often under the label of 'assumptive will' (Thomson and Martinet, I996, Declerck, I99 I and 2006, Palmer, 200I), and with gonna (in contrast to going to which is controversial in this respect, see Celle, 2004 vs. Declerck, 2006: 350). Will has - like its equivalents in other Germanic languages - both temporal and epistemic meanings (it's usual to consider that there is always an element of epistemic modality in the meaning of will as a residue

1 The authors would like to thank the Swiss National Science Foundation, who funded our research on non-descriptive uses of temporal expressions (project $\mathrm{N}^{\circ}$ IOOOI2-I2O299/I) and the three anonymous referees whose comments and advice helped improve the quality of this paper.

2 Expressing abstract possibility (Palmer, 200I; Lyons, I977); henceforth 'epistemic'. 
of its diachronic origin). A close conceptual link between futurity and epistemic modality is a classical assumption of several semantic approaches, which consider that since the future is by nature uncertain, it follows that any utterance denoting a future eventuality bears an intrinsic epistemic modality, expressing only possible eventualities. ${ }^{3}$ On the contrary, our view is that one should not confuse inherent properties of real-world phenomena such as temporality (or what we think of temporality as such) with the fact that individuals can - and do - communicate (and understand) representations that are relatively independent of these ontological characteristics. In McKim and Davis's (I976: 233) words, "[it is] difficult to believe that metaphysical assumptions about determinism and indeterminism could have any direct bearing on the semantic interpretation of future-tensed statements". Thus, the future tense allows us to make a description of an event, outside of any evocation of a belief or attitude, in much the same way as the present or past tenses, despite the clear metaphysical asymmetry between the past and the future; in this case one describes an event, deemed certain or known in the future (i.e. a prediction presented as certain). This does not in any way prevent the intuitive fact that natural or ontological properties of the future may also be used in other situations, whereby one can make manifest, through the use of the future tense, that what is said is not the representation of a truth with a future time index, but rather a speculation about the future, the present or the past (epistemic readings). We argue that an epistemic reading of future tense utterances is triggered by a cognitive process of pragmatic accommodation.

We adopt the view that tenses encode instructions on how the eventuality is to be represented by the hearer through the position of temporal coordinates (Reichenbach's I980 [I947] Speech time (S), Event time (E) and Reference time (R) points) ${ }^{4}$ in the mental conceptualization of time, intervals of validity, and, in some cases, perspective-switching (as when the French imparfait needs contextual accommodation in order to express free indirect speech and other non-standard meanings). 5

Though the future tense(s) express(es) futurity, even by means of instructions and not through the activation of some concept of 'future', it may still be the case

3 The idea that the (formal) semantics of the future bears an intrinsic epistemic modality goes back at least to McArthur (1974).

4 Reichenbach (I947) is usually considered as having established the basis for the semantics of tense as combinations of coordinates on the Time line. S stands for speech point and designates the time of the utterance (the deictic present). E stands for point of the event and designates the point or span of time at which the eventuality holds. $\mathrm{R}$ stands for point of reference and designates the time from which the eventuality is considered. Although Reichenbach's model was amended and supplemented in various ways since then, the S, $\mathrm{E}$ and $\mathrm{R}$ coordinates themselves remain the standard notation.

5 For the conception of tenses as procedural expressions in the Sperber and Wilson tradition, see Nicolle (I997) and Saussure (2003). For a detailed account of point-of-view switching with the French Imparfait, see Saussure and Sthioul (I999 and 2005). 
that futurity conveys epistemic modality; it would follow that all future sentences express epistemic modality in some way. This is well-suited to utterances with a future tense expressing possibility or probability in the future, and might form the basis for explaining utterances with a future tense expressing possibility or probability in the present, which is the focus of this article. But then, obviously, all future utterances would be redundant with an epistemic marker, at least in part: in this case the marker's only role would be to specify a degree on the epistemic scale; furthermore, a future tense should be incompatible with a modal marker of certainty if that marker has scope over the proposition itself (and not over the modal value).

We quite classically take modal markers to be operators having scope over a proposition which they modify. A marker of epistemic modality can be explicit (this is the case with may and adverbs such as maybe and probably, in French peut-être or probablement). Often, however, it is difficult to assess whether a marker is explicitly epistemic or if the epistemic interpretation stems from contextual accommodation; this is the case with must and devoir, which both have root and epistemic readings that depend on contextual factors. The same also holds with French pouvoir, which has both root and epistemic readings. Epistemic modality can also be conveyed implicitly, that is, via an accommodation of the whole utterance to the context. This happens if a non-epistemic reading causes an inconsistency with the current context. We suggest that this typically happens in epistemic readings triggered by the future tense in contexts where the eventuality cannot be interpreted as happening in the future. In a case like (I), below, the modal marker is not discernible and the epistemic reading is only available if it is mutually manifest to the interlocutors that the doorbell just rang and that there is no absolute certainty about who just rang it (typically there is no visual perception of that person):

\section{(I) [On sonne à la porte.] Ce sera le facteur.}

Here the speaker uses a future tense to refer to a probable eventuality in the present (it is the postman who just rang the bell), thereby displacing the focus of a future event into the present (or conversely, projecting him/herself from the present into the future). The observable effect here is that the hearer understands the speaker's utterance as a probability calculation, thus resolving the inconsistency of the speaker manifesting an assumption about the future when it's obviously about the present.

The aim of this paper is to provide a pragmatic account of such usages of the future tense. Our general assumption follows the classical analysis in which the epistemic future in French represents a future verification of a possible state of affairs in the present (or in the past, as with the anterior future); we insist that it does not necessarily express a possible explanation of a perceived state of affairs, as is sometimes suggested. We posit that the representation of a future verification is an allocentric representation, that is, a representation attributed to an utterer other than the Speaker at the time of speech (hence representing a third party's point of 
view $)^{6}$ and, as such, it is efficiently analysed as an 'interpretive use' of the tense in the sense of Sperber and Wilson (I995), i.e. a case where what is represented by the utterance is not a fact but an allocentric thought about a fact. Finally, we suggest that the epistemic future in French, as a non-standard way of expressing epistemic modality, bears specific relevance in the present of speech, in the sense of inviting a particular course of action in the expectation of the future certainty of the situation considered. When such relevance in the present is not available, then an epistemic modality cannot be derived from the future tense.

\section{THE EPISTEMIC FUTURE IN FRENCH: DATA AND ANALYSIS}

\subsection{Background and hypotheses}

We will discuss the hypothesis that what is understood via an epistemic future utterance is not a future situation but a future time when the situation can be verified. This assumption was suggested by various authors and can be considered consensual (Wilmet, I976, Martin, I987, Vetters, I995, Vetters and Skibinska, I998; see also Bellahsène, 2007). It was developed in relevance-theoretic terms by Sthioul (I998) who formulates it as an interpretive usage of the future: these utterances, he explains, refer to the eventuality by means of an imaginary allocentric point of consciousness in the future, from which the truth of the eventuality can be verified and therefore assessed as a fact. In his words:

Le futur putatif appréhende une situation présente par le biais de l'explication qui en sera selon toute probabilité donnée quelques instants plus tard: l'énoncé rend ainsi compte d'une connaissance attribuée à une instance connaissant la situation, instance que le locuteur présente comme étant distincte de lui-même parce qu'il n'est pas en mesure de poser une affirmation avec certitude. (Sthioul, I998: 206).

This assumption will be the starting point for our demonstration. The imaginary or actual verification that is described in the future stems from the (future) perspective of an allocentric third party. In other words, the epistemic future stems from a represented thought. However, we will also see that this explanation, in turn, raises problems. In particular, we will show that the epistemic future does not necessarily represent an actual verification of a possible explanation for a present state of affairs.

The last point to be addressed here is the very nature of the epistemic representation raised by the future tense in these utterances. When epistemic attitudes are about verifiable facts in the world, they are, according to Lyons (I977), objective-epistemic: that $\mathrm{P}$ is possible is not only the speaker's belief but a proposition subject to truth-evaluation and can be questioned or evaluated by the interlocutor (therefore utterances like It is false that this dog may beat you are not odd). If the

6 The term allocentric is used in psychology when referring to the opposite of egocentricity. It is common in French linguistic traditions at least since the work of Damourette and Pichon (I9I I-I936), who typically use it when dealing with those uses of tenses that activate third party viewpoints such as free indirect speech with the imparfait. 
epistemic future in French is about verification, one could then expect that it is objective-epistemic. But if the verification is only envisaged in a different possible world, then the actual possibilities of verification in the egocentric world are not fulfilled; this would entail that the epistemic future falls within the category of subjective-epistemic utterances in Lyons' terms. Such utterances manifest epistemic attitudes as a matter of course, which are by nature mental states and thus cannot be questioned, since they are 'externally inscrutable' (Papafragou, 2006). A number of expressions of epistemic beliefs allow only for expressing these mental states. Typical examples of these are epistemic must in English and peut-être in French: one cannot comment on one of these 'must'-utterances in terms of truth or falsity ( ${ }^{*} I t$ 's false that Paul must be at the swimming pool and *C'est faux que Pierre est peut-être à la piscine, see Papafragou, 2006 and van der Auwera, 2003). In this respect, the French epistemic future seems indeed to behave like a subjective-epistemic utterance:

(2) *Il est faux que ce sera le facteur (subjective-epistemic reading).

That epistemic future utterances in French are subjective-epistemic is in accordance with the hypothesis that it expresses (among other contents) verifiability in the future by an allocentric third party. If we consider that epistemic enrichment can be a natural cognitive enrichment based on futurity, ${ }^{8}$ then a number of predictions can be made. First, the epistemic future should be available for any verifiable eventuality in the future. This implies that it should be natural with any state of affairs that is expected to continue for a relevant time (thus states and activities) but not with achievements, ${ }^{9}$ unless there is semantic or pragmatic access to the representation of a resultant state. Also, if it is true that the pragmatic enrichment is not procedurally triggered by the tense as a linguistic expression but rather by the futurity itself, then epistemic readings should be available with other future tenses, possibly with restrictions due to the specific properties of these tenses. We will check these predictions on the various future tenses available in French.

Let us now turn to the question of how the epistemic future functions in French. We will examine the main characteristics and restrictions imposed by linguistic and contextual factors; we will then look at the differences and similarities of these usages as between the simple, anterior and periphrastic futures. The hypothesis of future verifiability, since the verification is envisaged in terms of an allocentric point of view, does not entail actual verification. This last point is slightly tricky and may lead to unwarranted speculation on what is and what is not verifiable if verification were impossible but still remain a representational effect of the epistemic future. We will turn to this point further in the course of our discussion below.

7 Which does not necessarily make these utterances non-truth-conditional: see Papafragou (2006).

8 This in no way entails that all future utterances are epistemic. Modality, we suggest, is just a natural but optional pragmatic enrichment based on futurity.

9 'Achievements' are those eventualities which have no temporal extension (they occur instantaneously), such as reach the finish line, find one's keys, etc. They do not license temporal modifiers denoting duration (e.g. for 10 minutes). 


\subsection{The simple future}

The usual assumptions, endorsed for example by Celle (2004:187), are i) that the epistemic usage of the simple future in French is only possible with être and avoir, ii) that this usage is impossible with Ist and 2nd person subjects and iii) that it is rare in contemporary French (see Le Querler, I996, Tasmowsky and Dendale, I998 and Rocci, 2000: 244-245). We claim that these assumptions are too strong. We won't discuss here the alleged rarity (which is, incidentally, not a criterion for naturalness), which is contrary to our impressions. ${ }^{10}$

If we are to consider data through the lens of pragmatics, then first of all, we suggest that if it seems difficult to have a (deictic) personal pronoun with these usages, this is due to the lack of relevance involved in evoking a situation that is manifest to the speaker as 'modal' with a marker which is modally ambiguous:

(3) a-Qu'est-ce que tu fais?

$\mathrm{b}-$ ? Je mangerai une pomme. ${ }^{11}$

(4) a - Où est-tu en ce moment?

$\mathrm{b}-$ ? Je serai chez moi.

The oddness is due, we claim, not to grammatical or semantic factors but to purely pragmatic ones: it is pragmatically nonsensical that the speaker should epistemically evaluate the state of affairs about which s/he is uncertain, except in very special cases. ${ }^{12}$ Explicit modals are similarly unexpected if the situation is obviously true: Je mange probablement une pomme is odd unless the Speaker is blindfolded and must guess what $\mathrm{s} / \mathrm{he}$ is eating. The explanation for why Je mangerai une pomme, on its own, is even more difficult than je mange peut-être une pomme comes from the fact that epistemic modality must be inferred in the first case through the inconsistency of a future temporal reference with the speech situation, whereas modality is explicitly communicated via peut-être. An explicit modal marker such as peut-être or may, unambiguously forcing the epistemic reading, gives access to a context where the speaker doesn't actually know what s/he is eating. ${ }^{13}$ We suggest that

10 Some popular texts such as the Tintin comic strips, obviously understandable without question by all speakers of French, show a great number of epistemic futures (actually, mostly anterior futures). If Tintin can be suspected to have been written in an archaic or regional version of French, this only indicates that epistemic futures are available in that area, not that it is restricted to that area ( $f$. Vetters and Skibinska, I998, an idea which we reject). We have no doubt that a systematic corpus study, still to be pursued, would prove the epistemic future in French to be much more widespread than is often thought, even in spontaneous oral communication, except in some areas (it seems less popular in Parisian French for example). We quote below only a few authentic examples, but the authors have noticed a significant number of occurrences throughout various French-speaking areas; at least, epistemic futures are alive and well in central France, in Switzerland and in Belgium, in particular in the anterior future form (see also Dendale, 200I).

11 We use the question mark to refer to pragmatic oddness.

12 An analysis also suggested by Schrott (I997).

13 This is a scalar inference triggered for reasons of relevance (or as an outcome of the Gricean maxim of quantity): the possibility of a state of affairs known to be true is itself 
(3b) is strange because there is no accessible context in which one doesn't know what one is eating; however, perhaps ( $3 \mathrm{~b})$ is possible in the case of a guessing game, though in a register that is unusual for an oral conversation. The case of (4b) is similar: within a particular context - for instance that it is plausible or manifest that the Speaker does not know where $s /$ he is or what $s /$ he is doing $\mathrm{s} /$ he must infer their state and thus communicate the uncertain nature of their own inference to the hearer. He or she will then find this modal enrichment relevant, provided that future verification is accessible, as we will demonstrate below in more detail. It is therefore the rarity of the situation, or the difficulty in accessing such a context, that gives the impression of oddness in these cases. 'I may/could be at home' seems to automatically communicate that the Speaker is uncertain, ${ }^{14}$ since the modality is explicit. But the fact that one must admit an unlikely or difficult context (e.g., the Speaker was kidnapped, then returned home blindfolded - improbable events, indeed, but pragmatically improbable events, all the more so when $s$ /he is calmly communicating with an epistemic future) is a superficial problem. But whenever there is certain contextual evidence for the uncertain nature of the situation denoted, the modal reading of the future tense is accessible, even in the Ist person $(5 \mathrm{~b})$ and of course in the 2 nd person as well (6) or the Ist person plural $(7 b)$ - even if these readings may require an effort of contextualisation if envisaged abstractly:

(5) a - Tu n'es pas bien?

$\mathrm{b}$ - J'aurai une petite grippe, voilà tout.

(6) Tu auras une petite grippe, voilà tout.

(7) a-Que se passe-t-il?

b - Nous serons dans une zone de turbulences, voilà tout.

With vous as well, epistemic future usage is reputed odd, but it remains easy enough to see that occurrences like (8) (in the anterior future tense) or (9) (in the simple future tense) are perfectly natural to a native speaker's ear with the epistemic meaning:

(8) Vous aurez mal fermé la porte.

(9) Tu seras son bouc émissaire dans cette affaire.

Now, what about verbs other than être and avoir? Once again, we can see that the prohibition postulated by most of the literature is much too strong, as the following examples show: here, predicates denoting activities (contrary to what the literature generally assumes) and states combine without difficulty with the simple future in an epistemic reading:

true, but one doesn't pragmatically access the truth when mere possibility is expressed. It is noteworthy that when a doubt becomes pragmatically more accessible, the utterance becomes more compatible with the epistemic future with $j e$, as with 'Je me serai (donc) trompé!' (anterior future) as it is with other less explicit modal forms as well (as with J'ai dû me tromper mentioned by an anonymous referee).

14 Except, of course, if in a guessing game. 
(Iо) Son train traversera un tunnel [c'est pourquoi son téléphone mobile est inatteignable]. (Sthioul, 2007: I I 8).

(i I) Elle prendra son bain [c'est pour ça qu'elle ne répond pas au téléphone].

(I2) Il dormira [c'est pour ça qu'il ne répond pas au téléphone].

Bellahsène (2007: 254, n.4) notes a similar example presented by Chevalier et al. (1978: 352): Notre ami est absent. Il présidera quelque réunion. Notice that although (IO), (II) and (I2) are indeed natural, a progressive form would be predicted as preferred by the hypothesis of 'future verification', since the progressive explicitly entails the continuation of the eventuality, while with a simple future, the continuity has to be inferred if the predicates are not stative. Since progressive forms with activities are more natural than non-progressive forms when communicating that the eventuality is still taking place, predictably a native French speaker will find (I3), (I4) and (I5) even more natural than the above examples:

(I3) Son train sera en train de traverser un tunnel.

(I4) Elle sera en train de prendre son bain.

(I 5) Il sera en train de dormir.

Another kind of facilitation is provided by passivisation. Contrasting (I6) and (I7), both clearly possible in French, we note that (I7) gives easier access to an epistemic context of interpretation. The reason for this is, we suggest, that the passive form triggers an effect of non-boundedness and therefore better allows for an inference of permanence; this makes an example like (I7) very similar to examples with the anterior future (see below); however this point calls for a complex development which we cannot undertake here:

(I6) Des solliciteurs le retiendront à son bureau.

(I7) Il sera retenu à son bureau par des solliciteurs.

The 'future verification' hypothesis allows for the prediction that stative predicates should work perfectly with epistemic readings with the future tense, given an appropriate context, since they naturally trigger the inference of their permanence in some future without further computation (stative predicates, obviously, are atelic and thus don't trigger the inference of a result). We will see that, again, examples that seem odd with statives are so for purely pragmatic reasons. This is the case with (I 8), which might seem odd at first sight:

(I 8) ? Il connaitra Pierre [epistemic reading].

But as soon as there is some relevance in the speech situation that the individual in question might know Pierre, an example like (I8) does in fact become natural. Examples (19) and (20), where we spell out the contextual conditions for such relevance, are all the easier to interpret, as Pierre's relevant ability is made explicit:

(I9) a - J'ai une fuite dans ma salle de bains.

$\mathrm{b}$ - Demande à Pierre, il connaîtra un plombier! 
(20) a - J'ai un problème avec cette question.

$\mathrm{b}-$ Demande à Pierre, il connaîtra la solution! $!^{15}$

On the other hand, it should also be a consequence of 'future verifiability' that epistemic readings in future tense utterances cannot occur with achievements, since by definition, achievements have no permanence. The following examples confirm this hypothesis:

(2 I) * La bombe explosera [in the epistemic reading].

(22) * Max atteindra le sommet [in the epistemic reading].

However, achievements are possible if rephrased either in the anterior future or via a cleft construction with être. The anterior future, as a perfect, denotes a resultant state, which can be represented as persisting in the allocentric future of verification, which readily allows the epistemic reading as in (23) below. But then, the assumption is about a past eventuality (the summit has necessarily been reached at the time of speech), not a present one:

(23) Max aura atteint le sommet.

The case of the cleft construction, as in (24), which is more difficult to explain, adds elements supporting the hypothesis of an allocentric reading:

(24) Ce sera la bombe qui explose.

We suggest that (24) is interpreted as a represented thought or utterance, i.e., as an allocentric metarepresentation: a typical completion of such constructions is ...tu verras. Why? Our hypothesis is that etre requires one to mentally access a state, not an event; here, the state inferred in the verifiable future is the resultant state of an explosion, which, once observed, can allow the backward inference that 'it was a bomb' that caused the observable state.

15 An anonymous referee suggests that ( $19 \mathrm{~b}$ ) and (2ob) trigger hypothetical readings (equivalent to $\mathrm{Si}$ tu demandes à Pierre, il connaîtra la solution) instead of an epistemic one. We think the hypothetical condition is not what is expressed by these utterances, but more importantly, we suggest that even if it were the case, it would not in any way change the epistemic reading of the future clause. The only other option would be that the future clause expresses a description of a future state of affairs, which cannot be the case, since the only available 'hypothetical' reading of these examples is metalinguistic (the fact of asking Pierre cannot entail his knowing a plumber). In turn, if metalinguistic, then the second clause expresses an illocutionary force other than assertion, in this case an epistemic modality. In all plausible interpretations, here we obtain not a mere prediction expressing certainty (as with il te donnera le numéro de son plombier dont il est si content) but a (high) probability. The referee rightly observes that the degree of certainty expressed in this use seems higher that probability, with which we might agree, but we insist that (I9b) and (2ob) don't express certainty (even if equivalent to Je suis sûr que $P$, as the referee suggests, since je suis sûr que, despite semantic appearances, doesn't entail certainty). The epistemic reading of these examples is even clearer when the clause is modified with bien, which lowers the epistemic degree of commitment: Demande à Pierre, il connaitra bien un plombier, which is equivalent neither to a si-clause nor to certainty. For more on degrees of certainty see Morency (2010: 202-205). 


\subsection{The anterior future}

With the epistemic anterior future, the Speaker expresses an explanation inferred from a resultant state, true at the time of speech, but triggered by an eventuality understood as occurring in the past. In other words, the modality here has scope over a past eventuality based on the observation of a fact true at the time of speech S. Still, both the eventuality and the resultant state are represented as verified at a future time:

(25) [Paul is late] Il aura manqué son train.

(26) [The Speaker failed to reach his correspondent by phone] Il aura traversé un tunnel.

Note that there is more flexibility than is generally admitted in epistemic usages, namely in the Ist and 2nd persons once again; similarly, the aspectual constraints seem much weaker than expected. In our view, this is clearly because the verbs avoir and être cancel the aspectual limitations through the representation of a resultant state epistemically represented at the time of speech (having missed the train or having been in a tunnel, will trivially remain true at the represented future time of verification if they are true at $\mathrm{S}$ ).

In relation to the use of $I$ or you, it is not surprising that the memory of a past event does not have the same knowledge status that a situation perceivable at the time of utterance has; hence the naturalness of epistemic anterior futures with (deictic) personal pronouns, compared to the sophisticated contexts it is necessary to have in order to find accessible cases for the simple epistemic future in a similar situation:

(27) Je me serai fait piquer par un insecte.

(28) Tu te seras fait piquer par un insecte.

It is thus, as we proposed earlier, essentially a question of the manifestness of the relevant facts that pragmatically come into play to render such utterances acceptable. This, again, shows how much the semantic constraints are far less crucial than the cognitive, representational, ones, when it comes to licensing the epistemic interpretations of future tense utterances.

\subsection{The periphrastic future}

What the French grammarians Damourette et Pichon (I9I I-I936: 279-282) said of the periphrastic future (PFUT) in French remains the usual, and we think, correct, way of describing it: the periphrastic future communicates that the conditions for the future eventuality's occurrence are met in the present (hence a mother saying to her child, upon leaving for an appointment: Tu joueras encore ('you play-FUT again'), meaning 'you will play again (when we come back)' and not Tu vas encore jouer (PFUT), meaning 'you will still play (now)'). It is then expectable that the epistemic effect, which calls for the present situation to continue into the future of verification, is also possible with the PFUT. This prediction is correct: 
(29) Ça va être le facteur [the doorbell just rang].

(29) typically receives an epistemic interpretation; though the simple future may not be very frequent with an epistemic reading, our intuition is that periphrastic futures with epistemic readings are very common in contemporary informal oral communication, just as the periphrastic future tends to be more closely connected with oral communication than the simple future.

However, we note the increased difficulty for non-stative verbs to allow epistemic readings with the PFUT (but verbs other than être or avoir are clearly possible, as in Demande à Pierre, il va savoir la réponse):

(30) Marie va prendre son bain [*epistemic reading].

(3I) Son train va traverser un tunnel [*epistemic reading].

The periphrastic future imposes a reading where the preparatory conditions are fulfilled in the present (probably because of the present tense of the auxiliary, and perhaps because of some residue of the primary meaning of aller. In (29), the typical interpretation is that of an allocentric subject (possibly the speaker herself) proving the egocentric speaker right in the near future by a representation of the form 'it really is the postman that just rang'. More precisely, the typical interpretation is that 'it is going to be the postman in front of me when I open the door in a minute'. A reading of this kind is unavailable without être, and, as a consequence, epistemic readings are allowed with progressive utterances like (32) or (33), as one would expect:

(32) A l'heure qu'il est, Marie va être en train de regarder la télé, pas de soucis.

(33) Son train va être en train de traverser un tunnel.

EPISTEMIC FUTURES BEARING CAUSAL-EXPLANATORY RELEVANCE

\section{TO THE PRESENT OF SPEECH}

We posited that epistemic futures are interpreted as metarepresentations of a real or imaginary future verification of the eventuality denoted or resultant state, following Sthioul (I998). By proposing examples for which an actual verification is conceivable and contrasting them with examples where such verification seems intrinsically impossible, we might think we have obtained an indication of this verification criterion, namely that the interpretation of an epistemic future projects a future allocentric subject ${ }^{16}$ who knows the situation. The following examples, which represent situations that cannot conceivably be verified in any future, indeed seem odd (although we will later qualify their oddness and explain it in terms of purely pragmatic factors):

(34) ? L'univers sera sphérique [epistemic reading].

(35) ? Dieu sera indulgent avec lui [epistemic reading].

${ }^{16}$ An enunciator distinct from the speaker at S. See footnote 6 on allocentricity. 
(34) and (35) represent situations that cannot be verified in any conceivable future. ${ }^{17}$ These examples present a real puzzle, which we will try to address now. First of all, we note, following Rocci, ${ }^{18}$ that there are indeed examples such as $(36)$ in which no verification in the future is conceivable but which are at the same time perfectly natural as epistemic futures:

(36) Il sera mort en pensant à sa femme.

We briefly mentioned that what we mean by future verifiability does not inhibit the factual, concrete, actual verifiability of the events in play. In (36), the Speaker projects a future consciousness which knows the thoughts of the deceased; and this is perfectly acceptable since human representation is not limited by ontological reality. So we will seek a different explanation for the apparent oddness of (34) and (35).

The staging of an imaginary consciousness in the future capable of actually verifying the fact is for us a hypothesis to be articulated with the hypothesis of the epistemic future as an interpretive usage of the tense, that is, an interpretation of a situation represented as being observed from a different viewpoint than the speaker's at speech time. We agree that this explanation is complex, but it is in keeping with our intuition relative to the meaning effects produced by an utterance like (36): the Speaker is not just making a simple conjecture but is adding a particular component of meaning which to us seems captured by this notion of representation of an allocentric consciousness. In other words, the Speaker communicates that 'something similar to a future eventuality will prove me right', and the fact that this future is factually impossible and known as such is a different question entirely. Thus what remains to be understood is the status of examples like (34) and (35), which we marked as potentially odd. Unsurprisingly, we will, in fact, defend the view according to which this oddness is, yet again, due to contextual, pragmatic factors. However, before doing so we need to provide some details about these pragmatic factors.

Our hypothesis relies on a more specific effect of the epistemic future. Not only do future utterances imply an epistemic reading - through metarepresentations - of an allocentric verification in a real or imaginary future, but their relevance is also directly linked to the actual speech situation. More precisely, the epistemic future is possible only in cases where the represented eventuality has a causal impact on a fact currently relevant to the interlocutors, or an impact on the actions to be presently undertaken in relation to the situation represented. We will develop this point in our concluding remarks; but we already note that, for example (34), if the spherical nature of the universe were relevant for the interlocutors at speech time, then the epistemic reading would seem quite natural; it is the difficulty of imagining such a context - again - which restricts this possibility and makes it apparently odd.

17 We notice, as mentioned in the introduction, that if epistemic futures were to be understood as denoting truths in other possible worlds, then (34) and (35) should be natural.

18 Personal communication. 
(35) is problematic because it is difficult to imagine a context where the utterance could serve as an explanation for something. Yet one need only imagine a play, staged in the afterlife, where certain beings are surprised not to witness the arrival, in Hell, of a certain individual, a renowned sinner, thus making God's indulgence relevant and hence for $(35)$ to appear normal. It is thus the contextual - pragmaticpath, which widens out and shows what type of interpretation the epistemic future imposes: not only the projection of an allocentric subject into the future, verifying the fact, but also, and ultimately, the explanatory and causal nature of the fact for the present situation. It now seems necessary to take a closer look at the hypothesis that epistemic futures prompt the hearer to derive specific consequences from the situation they evaluate in the present.

An explanatory value, introducing a causal relation between the mutually manifest situation and the evaluated process - as well as a particular consequence in relation to the situation of interlocution - seems to apply. Canonical examples such as ce sera le facteur can be analysed thus: they explain the event (the doorbell ringing) and posit a consequence by some inference, for instance, that the expected letter has arrived, that there is no need to go to the door (if it was the neighbour's doorbell), that we can stay calm (if we are criminals fearing the arrival of the police) or some other similar situation. In non-canonical cases, like son train traversera un tunnel or elle prendra son bain, the explanatory parameter is present as well (for example this may well be the reason why the person called is not reachable), and a consequence in the present is also inferred (we have to be patient and try again later).

Yet a typical, spontaneous case, heard in a shoe shop in France, uttered by a salesperson to a customer (one of this article's authors) in search of a particular brand, seems to contradict our hypothesis: ${ }^{19}$

(37) Elles seront sur ce présentoir.

At first sight, there is no explanatory meaning in (37) concerning the present situation, simply because ostensibly there is no proposition in the context identifying a state of affairs to be explained.

Yet in considering competing forms, like (38):

(38) Je crois qu'elles sont sur ce présentoir.

We notice that in (37) the Speaker is committed to his belief, in terms of which he predicts that a verification would confirm this belief, and not merely a state of affairs presented as modal. In the situation where (37) was uttered, the salesperson spontaneously preceded the client to the stand in question in order to verify the asserted probability, a situation which is not similarly expected in the case of (38) (although, of course, it remains possible that the salesperson would decide to go and check, but this is not an expectation the hearer will entertain on the basis of linguistic parameters). Provisionally, we need to admit that an explanatory meaning in epistemic future utterances in French arises only when there is a state of affairs

19 This utterance was heard in a shop in the small town of Langogne, in central France. 
calling for an explanation; in other cases such as (37), only a more fundamental pragmatic effect of epistemic futures is triggered, to which we now turn.

\section{CONCLUDING REMARKS: EPISTEMIC FUTURES \\ AS A DEONTIC-PRACTICAL MODALITY?}

Epistemic futures in French trigger quite complex metarepresentations. They demand a particular enrichment, which is not a simple allocentric projection, since it is not the state of affairs that is described in the future, but a belief about a present state of affairs which is presented as being verifiable in the future, combined with a consequence at the time of speech. This makes the epistemic future resemble cases like the French imparfait of politeness (J'avais une question), or the counterfactual imparfait (Une minute de plus et le train déraillait), where a present situation is envisioned in a different temporality, a different possible world, in order to produce specific interpretive effects. For the epistemic future, these effects would thus be linked not only to the epistemic nature of a belief that is uttered, but also to a specific degree of speaker endorsement or commitment, which distinguishes it from explicit modal formulations like $I$ believe that $P$ or Perhaps $P$, or even $I t$ is likely that $P$.

It is sometimes assumed that the epistemic future in French has an evidential meaning, the probable state of affairs being shown as inferred. Bellahsène (2007: 257), recalling previous work ${ }^{20}$ in this respect, insists that the French epistemic future sets up an evidential relation of inference in a way similar to devoir. She explains: 'Cette relation d'inférence se fonde sur des faits observés dans le présent du locuteur' and 'le locuteur prend connaissance d'une situation qui appelle une explication.'

However, the idea that an evidential flavour of inference is present is somewhat speculative, in the absence of anything that might motivate it (contrary to what happens with devoir where the inference obviously relates to the necessity of the conclusion, given the premises). As for the explanatory function of epistemic futures, it seems to hold invariably only for the epistemic anterior future, as well as those epistemic simple futures which address causal impact (such as $(34-36)$ above). Although some - possibly most - epistemic utterances with the simple future also have an explanatory function, this is not the case in all situations. Clearly, the utterance of (37) does not have any explanatory function in relation to the present state of affairs: the customer's request for a specific brand of shoes is in no way explained by the shoes in question probably being on a particular stand.

We emphasized the fact that epistemic future utterances communicate consequences for the present state of affairs. In fact, this might somehow seem a trivial feature of oral communication. We would like, however, to turn our attention to a thought which goes beyond the semantic-pragmatic framework, therefore calling for further investigation. It seems to us that French epistemic

${ }^{20}$ Dendale (200I) and Vet et Kampers-Manhe (200I). 
future usage occurs in typical situations where the epistemic future is interpreted as giving rise to a deontic-practical conclusion, i.e. a conclusion about what should or should not be done, for practical purposes. Thus, the fact that it is a future enables one not only to communicate the ideas invoked in this article, but also to instruct the hearer to infer the necessary action to be undertaken or attitude to adopt, according to the new information introduced. ${ }^{21}$ It is at this level, we think, that the difference is the most clearly apparent between Son train sera dans un tunnel, which can typically be imagined in a context where the utterance prompts one to wait for a better time to call again, and Je pense que son train est dans un tunnel, which gives modal information of a factual type. The latter utterance is descriptive of the belief itself, certainly allowing for a particular attitude or action, but not implicating it outright. Inasmuch as the future tense relates to the future, it is not impossible that one of the effects of the epistemic usage - having scope over a present situation, but saying something about the future given the situation - is that the hearer derives a deontic-practical conclusion in the future, relating to what it is necessary to do or not do. It thus appears, if we are correct, that what makes such an utterance relevant by comparison with more explicit modalities is not an evidential inferential meaning but, rather, a prospective action or attitude to be adopted. That action or attitude is to be undertaken in order to better adapt to a forthcoming situation which is represented by the future tense utterance as being verified in the future by an allocentric subject witnessing its occurrence.

Addresses for correspondence:

Louis de Saussure, Patrick Morency

Institut des Sciences du Langage et de la Communication

Université de Neuchâtel

Espace Louis-Agassiz 1

2000 Neuchâtel

Switzerland

e-mail:louis.desaussure@unine.ch,patrick.morency@unine.ch

\section{REFERENCES}

Bellahsène, L. (2007). L'expression de la conjecture: le cas du futur en français. In: D. Bouchard, I. Evrard and V. Etleva (eds), Représentations du sens linguistique. De Boeck: Bruxelles.

Celle, A. (2004). The French future tense and English will as markers of epistemic modality. Languages in Contrast, 5:2: I 8 I-2 I 8.

Chevalier, J.-C., Blanche-Benveniste, C., Arrivé, M. and Peytard, J. (I978). Grammaire Larousse $d u$ français contemporain. Paris: Larousse.

Damourette, J. and Pichon, E. (I9I I-I936). Des mots à la pensée. Essai de grammaire de la langue française. Paris: d'Artrey.

21 We think this may also explain how utterances with 'assumptive will' function in English, as well as the epistemic future usages of Romance languages other than French. 
Declerck, R. (1991). Tense in English. Its Structure and Use in Discourse. London: Routledge.

Declerck, R. (2006). The interaction between the English tense system and some modal and aspectual concepts. Cahiers de praxématique, 47: 49-73.

Dendale, P. (200I). Le futur conjectural versus devoir épistémique: différences de valeur et de restrictions d'emploi. Le français moderne, 69: I-20.

Le Querler, N. (1996). Typologie des modalités. Caen: Presses Universitaires de Caen.

Lyons, J. (1977). Semantics. Cambridge: Cambridge University Press.

McArthur, R. P. (I974). Factuality and modality in the future tense. Noûs, 8: 283-288.

McKim, V. R. and Davis, C. C. (1976). Temporal modalities and the future. Notre Dame Journal of Formal Logic, XVII/2: 233-239.

Martin, R. (1987). Langage et croyances. Bruxelles: Mardaga.

Morency, P. (20 IO). Enrichissement épistémique du futur. Cahiers Chronos, 2 I: I97-2 I 4.

Nicolle, S. (I997). Conceptual and procedural encoding: Criteria for the identification of linguistically encoded procedural information. In: M. Groesfema (ed), Proceedings of the University of Hertfordshire Relevance Theory Workshop. Hatfield: Peter Thomas, pp. $47-56$.

Palmer, F. R. (200I). Mood and Modality. Cambridge: Cambridge University Press.

Papafragou, A. (2006). Epistemic modality and truth-conditions. Lingua, I I6: I688I702.

Reichenbach, H. G. (1980 [1947]). Elements of Symbolic Logic. New York: Free Press.

Rocci, A. (2000). L'interprétation épistémique du futur en italien et en français: une analyse procédurale. Cahiers de Linguistique Française, 22: 24I-274.

Saussure, L. de (2003). Temps et Pertinence. Eléments de pragmatique cognitive du temps. De Boeck-Duculot: Bruxelles.

Saussure, L. de and Sthioul, B. (I999). L'imparfait narratif: point de vue (et images du monde). Cahiers de Praxématique, 32: 167-I88.

Saussure, L. de and Sthioul, B. (2005). Imparfait et enrichissement pragmatique. Cahiers Chronos, I4: I03-I20.

Schrott, A. (1997). Futurität im Franzözischen der Gegenwart. Tübingen: Narr.

Sperber, D. and Wilson, D. (1995). Relevance: Communication and Cognition. Oxford: Blackwell (2nd edition).

Sthioul, B. (1998). Temps verbaux et points de vue. In: J. Moeschler, J. Jayez, M. Kozlowska, J.-M. Luscher, B. Sthioul and L. de Saussure (eds.), Le temps des événements. Paris: Kimé, pp. I97-220.

Sthioul, B. (2007). Informations conceptuelle et procédurale: la piste beauzéenne. In: L. de Saussure, J. Moeschler and G. Puskas (eds), Information temporelle, procédures et ordre discursif. Amsterdam, New York: Rodopi, pp. Iо5-I2 I.

Tasmowski, L. and Dendale, P. (I998). Must/will and doit/futur simple as epistemic modal markers. Semantic value and restrictions of use. In: J. E. van der Auwera (ed.), English as a Human Language. To honour Louis Goossens. Munich: Lincom Europa, pp. $325-336$.

Thomson, A. J. and Martinet, A. V. (1996). Practical English Grammar. Oxford: Oxford University Press.

van der Auwera, J. (2003). La grammaire de la modalité. In: M. Jadir. (ed.), Développements récents en grammaire fonctionnelle. Mohammedia: Publications de la Faculté des Lettres de l'Université Hassan II Mohammedia, pp. ıо9-I20. 
Vet, C. and Kampers-Manhe, B. (200I). Futur simple et futur du passé : les emplois temporels et modaux. In: P. Dendale and L. Tasmowski (eds), Le conditionnel en français. Metz: Recherches linguistiques, 89-IO4.

Vetters, C. (I995). L'opposition passé simple-imparfait : une question d'aspect ou de structuration textuelle? Michigan: Bell \& Howell, UMI Dissertation Services.

Vetters, C. and Skibinksa, E. (1998). Le futur: une question de temps ou de mode? Remarques générales et analyse du 'présent-futur' perfectif polonais. In: A. Borillo, C. Vetters and M. Vuillaume (eds), Regards sur l'aspect III. Amsterdam: Rodopi, pp. $247-266$.

Wilmet, M. (1976). Grammaire critique du français. Louvain-la-Neuve: Duculot. 